International Journal of Engineering \& Technology, $7(4.20)(2018) 403-407$
SPC
SPebsite www.sciencepubco.com/index.php/IJET
Research paper

\title{
Improving the Shear Strength of Lightweight RC Thick Hollow Core Slab Made of Recycled Materials
}

\author{
Yousif Nassif Sabr ${ }^{1}$, Dr. Husain Khalaf Jarallah², Dr. Hassan Issa Abdul Kareem \\ ${ }^{1}$ Civil Engineering Department, Al-Mustansiriayah University, Baghdad, Iraq \\ ${ }^{2}$ Civil Engineering Department, Al-Mustansiriayah University, Baghdad, Iraq \\ ${ }^{3}$ Civil Engineering Department, Al-Mustansiriayah University, Baghdad, Iraq \\ *Corresponding authorE-mail:yousifnasef@ gmail.com
}

\begin{abstract}
This research paper focused on the experimental study about shear behavior of reinforced concrete thick hollow core slab. The reduction hollow length technique was used to resist the shear failure that occurred in the thick hollow core slab. The three hollows were used in tested slabs. The effect of reduction in the length of hollow in the shear region as well as the sides hollow was considered in the shear behavior of the tested hollow core slab. The recyclable material was used to a get of lightweight concrete, where the crushed clay brick was used as a coarse aggregate instead of the gravel. The test was done by applying two line load. The specimens were tested up to failure. The experimental results showed an increase in the shear strength up to $109.52 \%$ and an increase in the deflection up to $24 \%$ compared with the hollow core slab specimen that all hollow core is accessible. From the experimental result of this investigation can avoid the shear failure subsequently the load devolves from the shear region to the flexural region with change the mode of failure from shear failure to flexural-shear failure.
\end{abstract}

Keywords: Hollow core slab, lightweight concrete, improving shear strength, shear stress, crushed clay brick

\section{Introduction}

The precast prestresses hollow core slab (HCS) was used since the $1950 \mathrm{~s}$ [1]. HCS is a precast, prestress or non-prestress concrete slab with consistent voids which extend throughout the length of the slab to decrease weight and cost, and as a part of advantage, to utilize for disguised electrical or mechanical runs. Likewise, HCS has application as spandrel members, wall panels, and bridge deck units. Span length of HCS reaches up to $(18 \mathrm{~m})$ without columns or any supporting members. HCS system can be utilized for an extensive variety of utilization requiring floor or roof systems. This system can be in a perfect world utilized as a part of private, business, auto parks or unaired development ventures. HCS system provides extreme structural efficiency with the use of HSC, yet at the same time requiring low material consumption [2].

Cuenca and Serna provided a description for use fiber-reinforcement concrete (FRC) to resist the shear strength in HCS. The variables were used two quantity of steel fibers with hooked-end (50 and 70) $\mathrm{kg} / \mathrm{m}^{3}$ with dimension $40 \mathrm{~mm}$ in a length and $0.62 \mathrm{~mm}$ in a diameter with an aspect ratio of $65 \%$. The result showed the HCS specimens with steel fiber achieved an increase of the ultimate load of about $30 \%$ and more ductility than the HCS specimens without steel fiber [3].

Wu et al. explored an innovative technique for resisting the webshear capacity of hollow core slab by bonding external fiber-reinforced polymer sheets (FRP) along the internal perimeter of the slab voids. Experimental testing was done on the part cut from the width of hollow core slab specimens. The thickness of HCS was $300 \mathrm{~mm}$, the diameter of the hollow core was $243 \mathrm{~mm}$ and length of specimens was $4499 \mathrm{~mm}$. The variables of this work were used the different length of FRP $(0,300,450$ and 600)mm, it was used one layer and two layers of sheet FRP. The result showed an increase in the length of sheet FRP from $300 \mathrm{~mm}$ to $600 \mathrm{~mm}$ for both one and two layers increase the shear strength up to $45 \%$. Use sheet FRP, not only increase the shear capacity but increase also the ductility [4].

Lightweight concrete (LWC) has successfully been utilized for long times for structural members and systems in building and bridges. In addition to its lighter weight, which grants sparing in dead loads, and thus decreases the costs of both superstructure and foundation, it is more impervious to fire and gives preferable heat and sound protection than concrete of normal density [5] [6]. LWC is considered as having a density not exceeding $1920 \mathrm{~kg} / \mathrm{m}^{3}$, while normal density concrete is considered to have a usual density ranging between $2240 \mathrm{~kg} / \mathrm{m}^{3}$ and $2480 \mathrm{~kg} / \mathrm{m}^{3}$, and the minimum compressive strength at 28 days is $17 \mathrm{MPa}$ [7]. LWC with cylinder compressive strength (f 'c) greater than $41 \mathrm{MPa}$, it is characterized as high strength concrete (HSC) [7].

\section{Research Significance}

The shear behavior is need to exam for thick HCS produced from recycled material in order to reach safe and low cost in the construction of HCS.

\section{Experimental Program}

The experimental work includes cast three HCS specimens with dimensions $(1200 \mathrm{~mm}$ length, $450 \mathrm{~mm}$ width and $200 \mathrm{~mm}$ ) with three circular hollows with same diameter $75 \mathrm{~mm}$. The first specimen is content three hollows open through the length and symbolizes as 
(HCS-200-A), the second specimen is content one hollow decreased in hollow length and symbolizes as (HCS-200-B), and the third specimen is content two hollows decreased in hollow length and symbolizes as (HCS-200-C). The HCS specimens were designed according to ACI-318M-14 [8]. The steel reinforcement is constant for all specimens. The main reinforcement is $4 \varnothing 10 \mathrm{~mm}$ and the second reinforcement is Ø8@80mm. The details of HCS specimens are gives in (Fig. 1, 2 and 3). The HCS was consider thick as per (The HCS specimens were selected to ensure thick plat, the thickness to clear span ratio $\frac{h}{l_{n}}<\frac{1}{5}$ where $\mathrm{h}$ is thickness of slab and $l_{n}$ is clear span) [9].

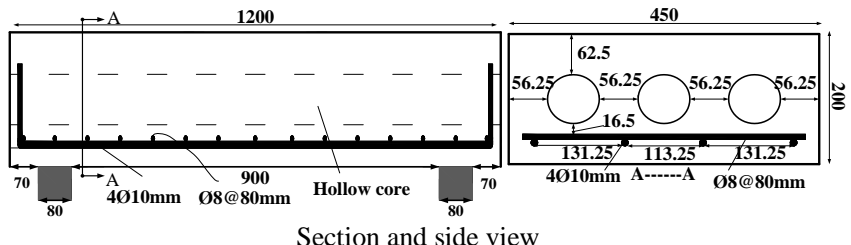

Section and side view

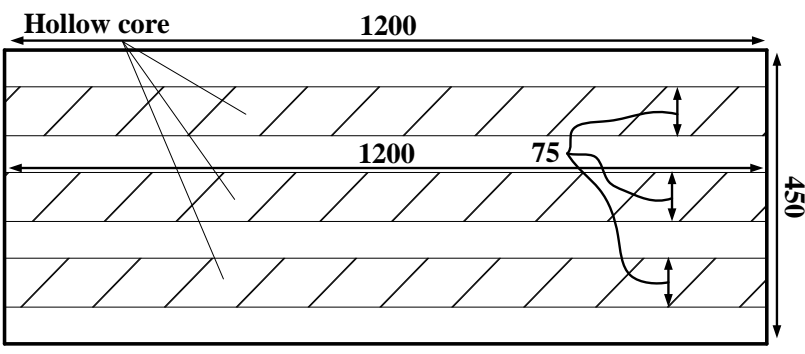

Top view

Fig. 1: HCS Specimen (HCS-200-A) (All Dimensions in mm)
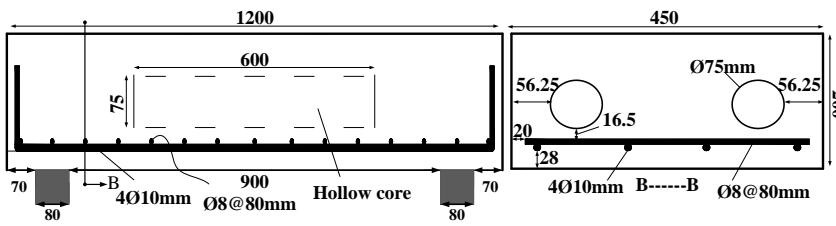

Section and side view

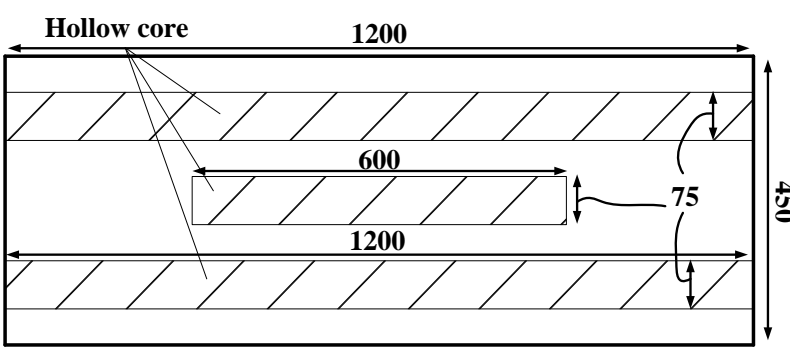

Top view

Fig. 2: HCS Specimen (HCS-200-B) (All Dimensions in mm)

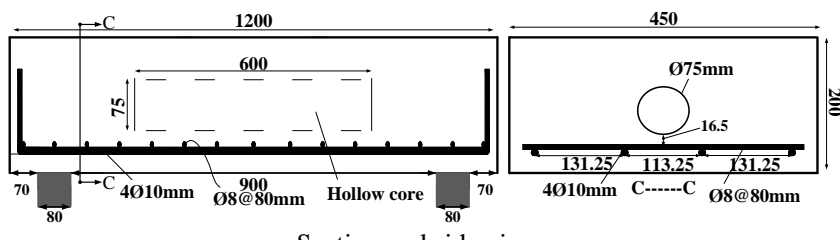

Section and side view

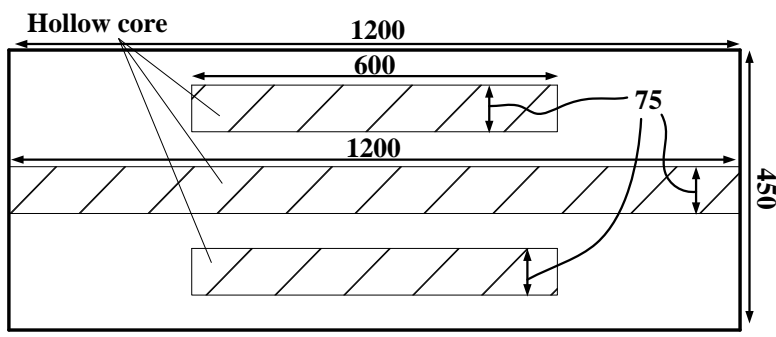

Top view

Fig. 3: HCS Specimen (HCS-200-C) (All Dimensions in mm)

\section{Materials}

The lightweight concrete is used in this research. The crushed clay brick (CCB) was used as a coarse aggregate. The details of concrete mix shown in the (Table 1). The test of steel reinforcement was done according to ASTM A615-05 [10]. The properties of steel reinforcement shown in (Table 2).

Table 1: Details of Concrete Mix

\begin{tabular}{c|c}
\hline Parameter & Content \\
\hline Cement $\mathrm{kg} / \mathrm{m}^{3}($ Ordinary Portland Cement Type I) & 485 \\
Sand $\mathrm{kg} / \mathrm{m}^{3}($ maximum size $4.75 \mathrm{~mm})$ & 500 \\
Crushed Clay Brick (CCB) $\mathrm{kg} / \mathrm{m}^{3}$ (maximum size & 712 \\
$12.5 \mathrm{~mm})$ & \\
Silica Fume $\mathrm{kg} / \mathrm{m}^{3}(10 \%$ of Cement weight $)$ & 48.5 \\
Iron Powder Waste $\mathrm{kg} / \mathrm{m}^{3}$ (1\% of Cement weight) & 4.85 \\
Superplasticizer liter $/ \mathrm{m}^{3}$ (1 \% of Cement weight) & 4.85 \\
water liter $/ \mathrm{m}^{3}(0.31$ of Cement weight $)$ & 150 \\
\hline
\end{tabular}

Table 2: Details of Test Steel Reinforcement*

\begin{tabular}{|c|c|c|c|c|c|}
\hline $\begin{array}{c}\text { Bar } \\
\text { Nomi- } \\
\text { nal } \\
\text { diame- } \\
\text { ter } \\
(\mathrm{mm})\end{array}$ & $\begin{array}{c}\text { Bar } \\
\text { Meas- } \\
\text { ured } \\
\text { diame- } \\
\text { ter } \\
(\mathrm{mm})\end{array}$ & Bar Type & $\begin{array}{l}\text { Yield } \\
\text { strength } \\
\text { (fy) } \\
\text { (MPa) }\end{array}$ & $\begin{array}{l}\text { Ultimate } \\
\text { strength } \\
\text { (fu) } \\
(\mathrm{MPa})\end{array}$ & $\begin{array}{l}\text { Elonga- } \\
\text { tion } \\
\quad \%\end{array}$ \\
\hline 8 & 7.83 & Deformed & 582 & 696 & 12.5 \\
\hline 10 & 10.05 & Deformed & 524 & 650 & 13 \\
\hline
\end{tabular}

*Each value is an average of three specimens (each $50 \mathrm{~cm}$ length)

\section{The Molds and Preparation for Cast}

The mold was used in this research is made of plywood with thickness $(15 \mathrm{~mm})$. The dimensions of molds were $1200 \mathrm{~mm}$ in length, $450 \mathrm{~mm}$ in width and $200 \mathrm{~mm}$ in thickness. The circular hollows were made by using PVC pipe with diameter $75 \mathrm{~mm}$. Then the PVC pipes installed inside the mold to reach circular hollows as shown in the (Fig. 4). The internal face of the mold cleaned and oiled to avoid adhesion concrete with molds and the net of steel reinforcement placed inside the mold.
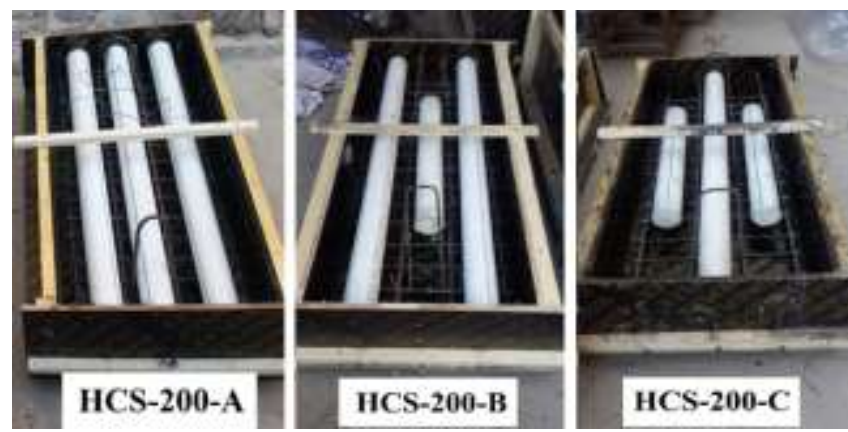

Fig. 4: Install Pipe and Steel Reinforcement in The Molds

\section{The Test Process of HCS Specimens}

The test of HCS specimens was done in the Construction Engineering laboratory, college of Engineering, Al-Mustansiriayah University Baghdad Iraq. The HCS specimens were tested up to failure under two-line load with step load $5 \mathrm{kN}$. The dial gauge was used to measure the deflection at mid-span. The test machine is shown in (Fig. 5). The strain gauge was used to measure the strains that occurs due to applied the load in the top fiber of concrete to measure the strain in the compression zone (S.G.1), in the side face of concrete to measure shear stress (S.G.2) and in the flexural steel reinforcement to measure the strain in the tension zone (S.G.3) as shown in the (Fig. 6 and 7). 


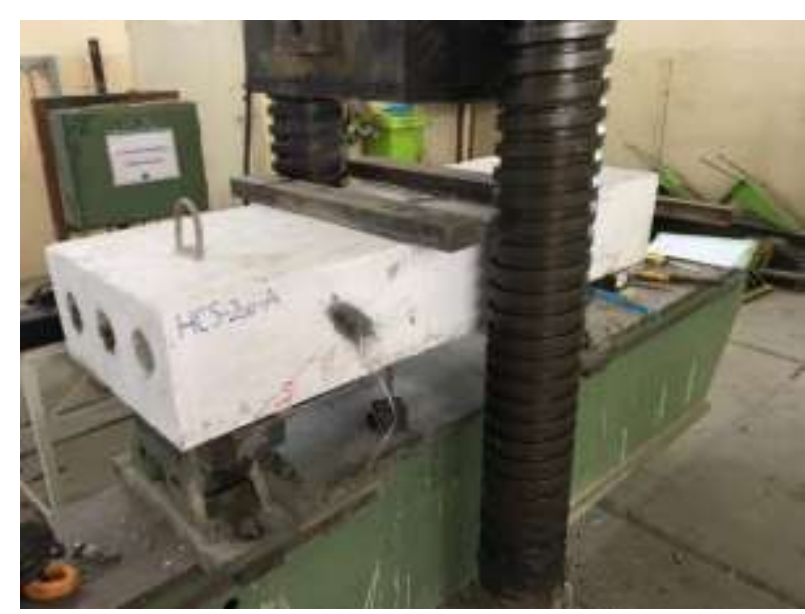

Fig. 5: The Test Machine

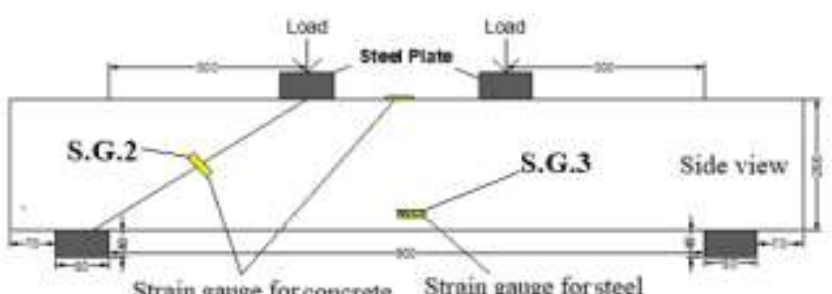

Strain gatige for concrete Strain gauge for steel

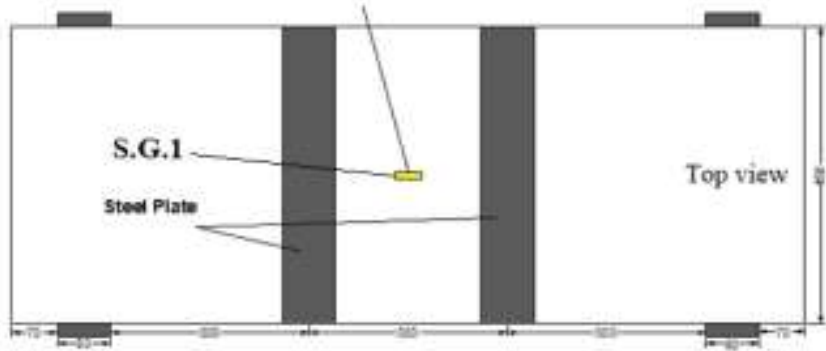

Fig. 6: Location of Strain Gauge at Concrete and Steel

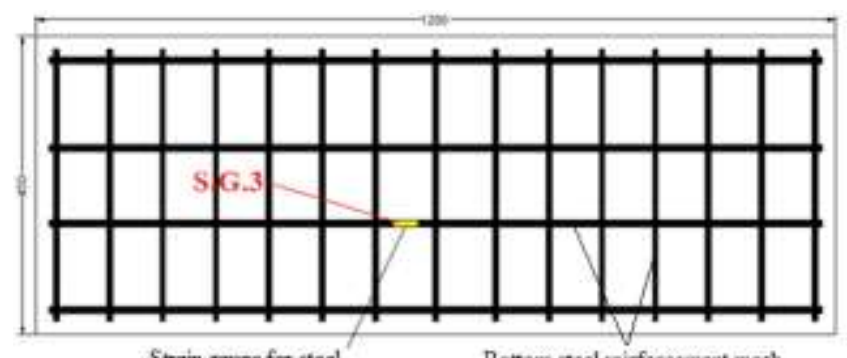

Strain garase for st

Bottom steel reinforcement mesh

Fig. 7: Location of Strain Gauge at Steel Reinforcement

\section{Results and Discussion}

\subsection{Testing of Fresh Concrete}

The slump test was used to measure the workability of concrete according to ASTM C 143 [11] as shown in (Fig. 8). The result of the test was $110 \mathrm{~mm}$.
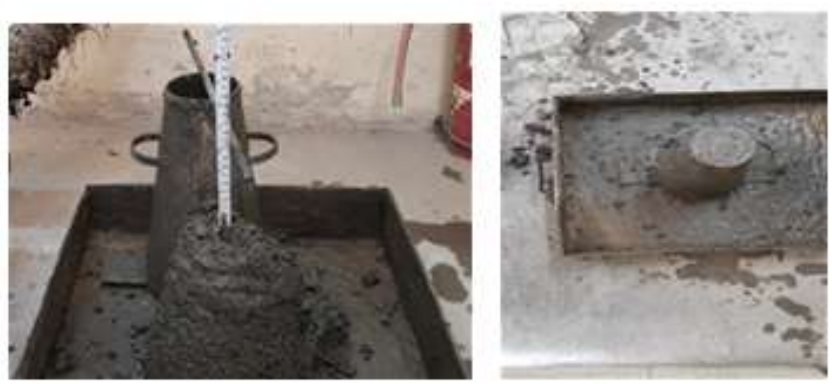

Fig. 8: Slump Test

\subsection{Testing of Hardened Concrete}

The mechanical properties results of LWC shown in (Table 3). The mechanical properties was conduct according to codes and standards listed in (Table 3 ). The density of the concrete was determined from the weight of average three cubes.

\begin{tabular}{c|c}
\multicolumn{2}{c}{ Table 3: Mechanical Properties of Concrete } \\
\hline Mechanical Properties & Results \\
\hline $\mathrm{f}_{\mathrm{cu}}(\mathrm{MPa})(\mathrm{BS} 1881-$ part116-2000 [12]) & 51 \\
$\mathrm{f}_{\mathrm{c}}^{\prime}(\mathrm{MPa})($ ASTM C39/C39M-05 [13]) & 42.3 \\
$\mathrm{f}_{\mathrm{ct}}(\mathrm{MPa})($ ASTM C496-04 [14]) & 3.1 \\
$\mathrm{f}_{\mathrm{r}}(\mathrm{MPa})($ ASTMC78-02 [15]) & 3.33 \\
$\mathrm{E}_{\mathrm{c}}(\mathrm{MPa})($ ASTMC469-02 [16]) & 24147 \\
Density $\left(\mathrm{kg} / \mathrm{m}^{3}\right)$ & 1910 \\
\hline
\end{tabular}

The results shows that the concrete is high strength concrete symbolizes $\left(\mathbf{f}_{\mathbf{c}}^{\prime}\right)$ is more compressive strength $41 \mathrm{MPa}$ according to ACI Committee 213R-03 [7]. The results for density showed that the concrete is LWC with density less than $1920 \mathrm{~kg} / \mathrm{m}^{3}$ [7].

\subsection{Test of HCS Specimens}

The first stage of test HCS specimens has placed the specimen in the machine test. The dial gauge was used for HCS specimen to measure the deflection in the mid-span. The load was done by the applied two-line load. The load was applied with steps $5 \mathrm{kN}$ with the record the deflection for each load step, and the strains measure up to the failure specimens. At early the HCS specimens free of apparent cracks. With increasing the load, the first crack can be seen at the mid-span in the tension zone then recorded the load at first crack $\left(\mathrm{P}_{\mathrm{cr}}\right)$, then with increasing the load more several cracks can be seen in the tension zone and the cracks become faster and spacious. The load continues to the extent of specimen failure; record the ultimate load $\left(\mathrm{P}_{\mathrm{u}}\right)$ and maximum deflection $\left(\Delta_{\mathrm{u}}\right)$. The cracks were marked for clarifying. The result of the test HCS specimens shown in (Table 4) and the crack pattern is shown in (Fig. 9) through (Fig. 11). The experimental results showed a change in the mode failure. The mode failure change from the shear to flexural-shear failure. This change in mode failure due to the decrease hollow length increasing the concrete in the region near the support this is resisting the shear failure and convert the load to the mid-span causes increase in the maximum deflection in the mid-span.

Table 4: The Results of Test HCS Specimens

\begin{tabular}{c|c|c|c|c|c}
\hline Specimens & $\begin{array}{c}\mathrm{P}_{\mathrm{cr}} \\
(\mathrm{kN})\end{array}$ & $\begin{array}{c}\mathrm{P}_{\mathrm{u}} \\
(\mathrm{kN})\end{array}$ & $\begin{array}{c}\mathrm{V}_{\mathrm{u}} \\
(\mathrm{kN})\end{array}$ & $\Delta_{\mathrm{u}}(\mathrm{mm})$ & $\begin{array}{c}\text { Mode of } \\
\text { failure* }\end{array}$ \\
\hline HCS-200-A & 12.3 & 73.5 & 36.75 & 3.9 & $\mathrm{~S}$ \\
HCS-200-B & 14.4 & 115 & 57.5 & 4.2 & $\mathrm{~S}$ \\
HCS-200-C & 20 & 154 & 77 & 4.4 & $\mathrm{~F}-\mathrm{S}$ \\
\hline
\end{tabular}

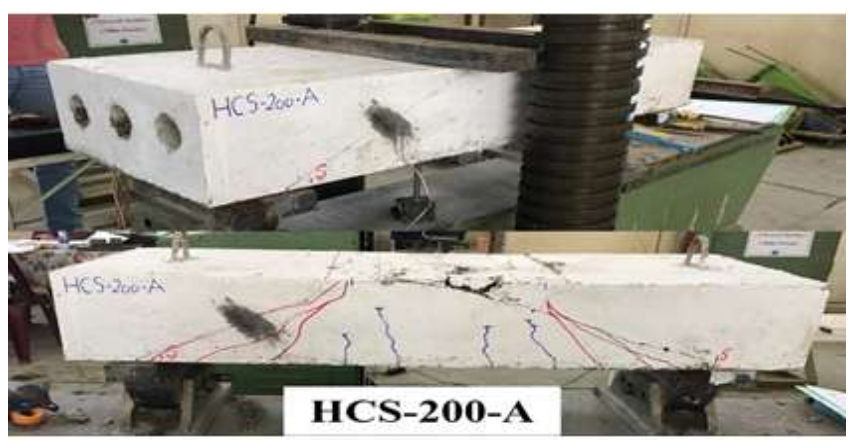

Fig. 9: Crack Pattern for HCS-200-A 


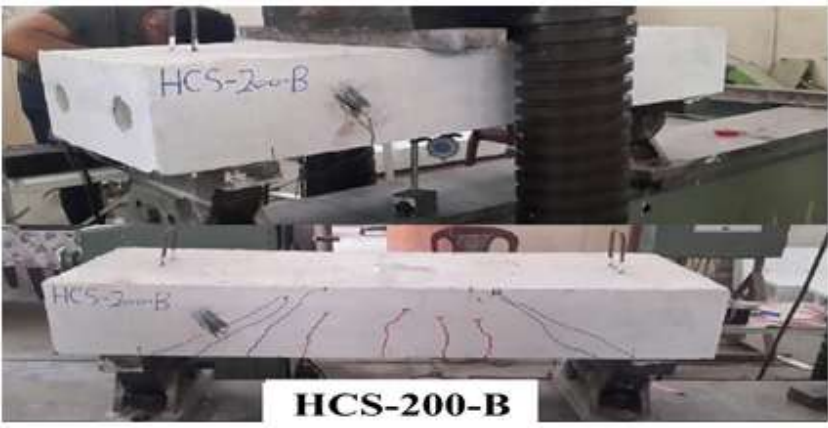

Fig. 10: Crack Pattern for HCS-200-B

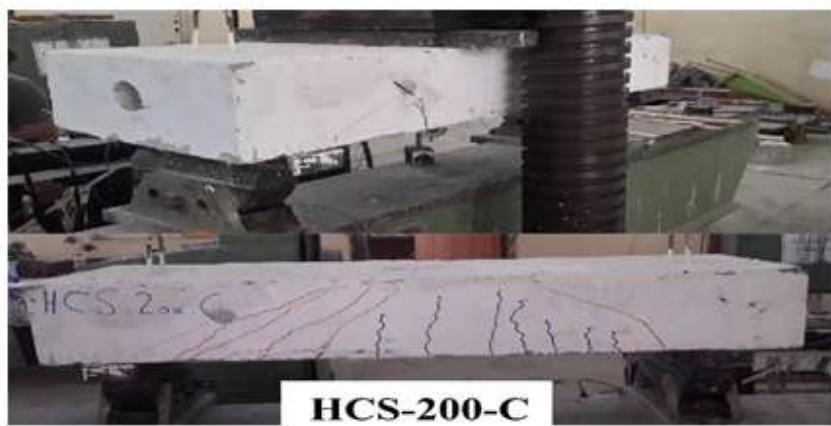

Fig. 11: Crack Pattern for HCS-200-C

\subsection{Effect of Hollow Length on The Ultimate Load and First Crack Load}

The experimental results showed in the (Table 5). The reduction one and two hollow length lead to increase the ultimate load up to $109.52 \%$ and increase in the first crack load up to $62.6 \%$ with slight increase in the unit weight up to $5.68 \%$ compare with HCS specimen which all hollow are accessible. This is due to increase in the cross-section area at a region near to the support by decreasing hollow length from each side of the span. This technical is resist the shear failure and work to convert the load to the mid-span thus change the failure mode.

Table 5: Effect of Hollow Length on The Ultimate Load and First Crack Load

\begin{tabular}{c|c|c|c|c|c|c}
\hline Specimens & $\begin{array}{c}\mathrm{P}_{\mathrm{u}} \\
(\mathrm{kN})\end{array}$ & $\begin{array}{c}\text { Ratio of } \\
\mathrm{P}_{\mathrm{u}}(\%)\end{array}$ & $\begin{array}{c}\mathrm{P}_{\mathrm{cr}} \\
(\mathrm{kN})\end{array}$ & $\begin{array}{l}\text { Ratio } \\
\text { of } \mathrm{P}_{\mathrm{cr}} \\
(\%)\end{array}$ & $\begin{array}{c}\text { Unit } \\
\text { weight } \\
(\mathrm{kg})\end{array}$ & $\begin{array}{c}\text { Ratio } \\
\text { of } \\
\text { weight } \\
(\%)\end{array}$ \\
\hline HCS-200-A* & 73.5 & - & 12.3 & - & 176 & - \\
HCS-200-B & 115 & +56.46 & 14.4 & +17.07 & 181 & +2.84 \\
HCS-200-C & 154 & +109.52 & 20 & +62.6 & 186 & +5.68 \\
\hline
\end{tabular}

\section{*Reference HCS Specimen}

\subsection{Effect of Hollow Length on Maximum Deflection}

From the experimental results shown in the (Table 6) and the (Fig. 12). The reduction in the length one and two hollow lengths from each side of HCS specimens lead to increase the maximum deflection in the mid-span. This is due to the decrease hollow length resist the shear failure thus become more stiffness and convert the load from the shear region to the mid-span, this is leads to increase the maximum deflection in the mid-span.

Table 6: Effect Hollow Length on Maximum Deflection

\begin{tabular}{|c|c|c|}
\hline Specimens & $\Delta_{\mathrm{u}}(\mathrm{mm})$ & Ratio of $\Delta_{\mathrm{u}}(\%)$ \\
\hline HCS-200-A* & 3.9 & - \\
\hline HCS-200-B & 4.2 & +7.7 \\
\hline HCS-200-C & 4.4 & +12.82 \\
\hline
\end{tabular}

*Reference HCS Specimen

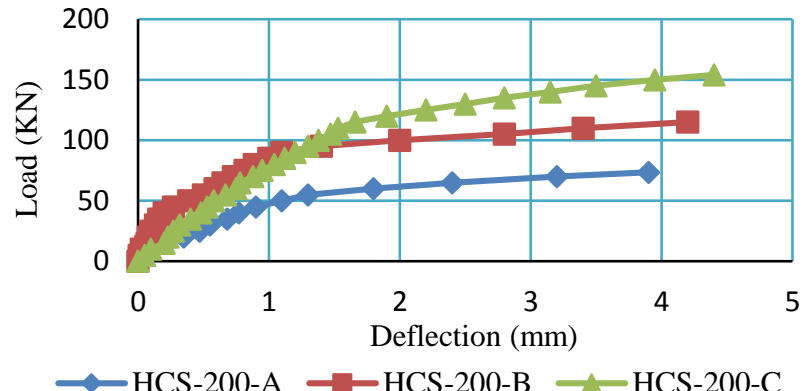

Fig. 12: Load-Deflection Curve for HCS Specimens

\subsection{Strain-Load Diagram}

The strain load diagram is shown in the (Fig. 13), it was depending on the strains was installed in the steel reinforcement (tension zone) and in the top fiber of concrete (compression zone) where compared both with the load applied with steps load $5 \mathrm{kN}$. The results showed the reduction in the one and two hollow lengths it causes an increase in the strains in the tension and compression zone. This is due to increase stiffens of the HCS specimens where the loads convert from the region support to the mid-span this leads to increase the strains in the tension and compression at mid-span. The yield strain of steel reinforcement was measured from the tension test of steel was shown in the (Table 2) the yield strain is 2620 micro strain. The yield load does not occur at tested HCS specimens. When lifting the load in stage failure the cracks was closed. This is due to the steel reinforcement in flexural is not reached to the stage of yield strength.

\subsection{Shear Stress in Concrete}

The shear stresses were determined from reading record by strain gauge (S.G.2). The readings of the strain gauge (S.G.2) for each specimen shown in the (Fig. 14). The maximum shear stress of HCS specimen was calculated by using Mohr's circle showed in the (Table 7). The experimental results showed that reduction in the length of one and two hollow lengths it causes a decrease in the shear stress.

Table 7: The Results of Shear Stress in Concrete

\begin{tabular}{c|c|c}
\hline Specimens & $\begin{array}{c}\text { Shear Stress }\left(\tau_{\text {Max }}\right) \\
(\mathrm{MPa})\end{array}$ & Ratio of $\tau_{\text {Max }}(\%)$ \\
\hline HCS-200-A* & 6.18 & - \\
HCS-200-B & 4.55 & -26.38 \\
HCS-200-C & 3.63 & -41.26 \\
\hline
\end{tabular}

*Reference HCS Specimen

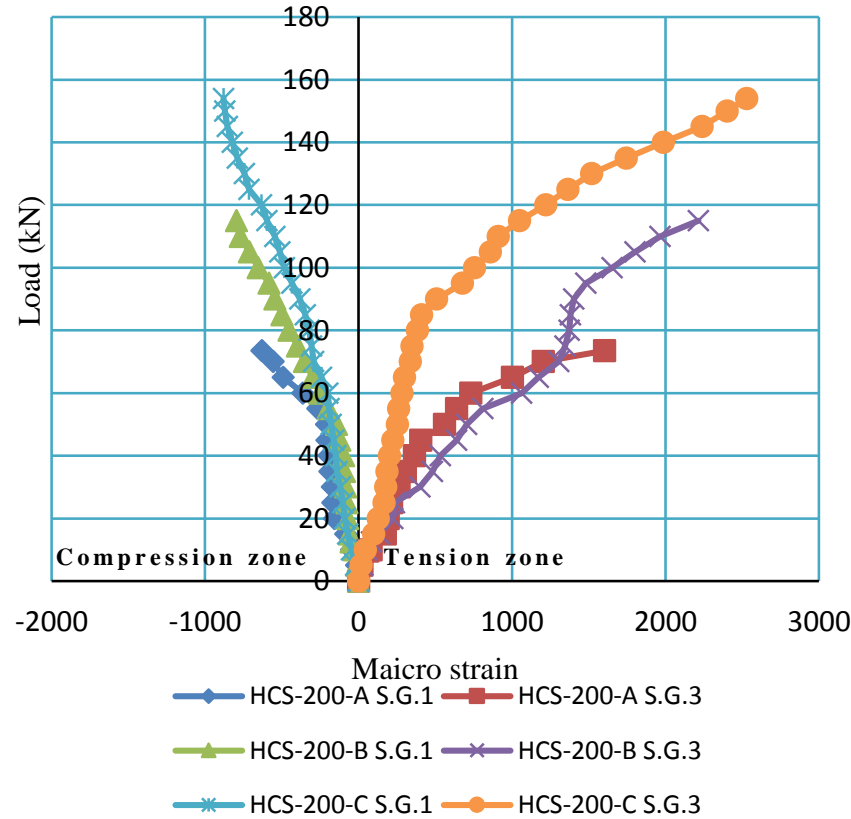

Fig. 13: Strain-Load Diagram for Strain Gauge S.G.1 and S.G.3 


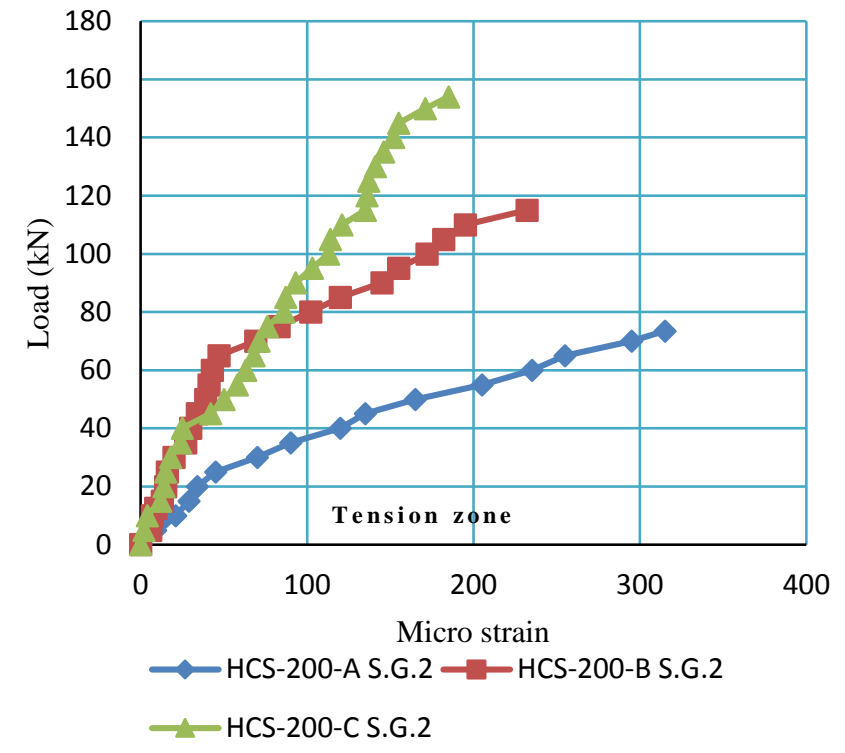

Fig. 14: Strain-Load Diagram for Strain Gauge S.G.2

\section{Conclusions}

According to the experimental results given in the research paper, the following conclusions are presented:

1-The techniques were used to resist shear failure showed an increase in the ultimate load, first crack load and in the maximum deflection up to $109.52 \%, 62.6 \%$ and $12.82 \%$ respectively.

2-The reduction in the length of one and two hollow length is lead to a slight increase in overall weight up to $(5.68 \%)$.

3-Improve the shear strength of HCS specimens by reduction in one and two hollow lengths change the mode failure from the shear failure to flexural-shear failure. The select the critical hollow length is required more studies by using different hollow core length.

4-The experimental results from the strain gauge showed the reduction in length of one and two hollow length lead to increase strains in the compressive zone and tension zone in the mid-span where the applied load was converted from the support region to the mid-span.

5-The shear stress of HCS specimens decrease up to (41.26\%) with a reduction in length of one and two hollow lengths compare with HCS specimens with all hollow are accessible.

\section{References}

[1] Hawkins, N. M., and S. K. Ghosh. "Shear Strength of Hollow Core Slabs" PCI Journal 51, 2006.

[2] Stephen, C., "Hollow Core Manufacture and Factory Design", the Indian Concrete Journal 2013.pp 20-25.

[3] Cuenca, E. and Serna, P., "Failure Modes and Shear Design of Prestressed Hollow Core Slabs Made of Fiber-Reinforced Concrete", ELSEVIER, 15 June 2012.

[4] Wu, Y., Cheng S., El-Ragaby, A. and Mehta, A., "Effectiveness of a Novel Technique in Strengthening Web-Shear Capacity of Prestressed Hollow Core Slabs Using Externally Bonded FRP Sheets", American Society of Civil Engineers (ASCE), 2016.

[5] Slate, F. O., Nilson, A. H. and Martinez, S., "Mechanical Properties of High Strength Lightweight Concrete", ACI Journal, Proceedings V. 83, No. 4, July-august 1986, pp.606-613.

[6] Mays, G. C. and Barner, R. A., "The Performance of Lightweight Aggregate Concrete Structure in Service", the Structure Engineer, Vol. 69, No 20, 15 October 1994, pp. 351-360.

[7] ACI Committee 213R-03, "Guide for Structure Lightweight-Aggregate Concrete", American Concrete Institute, USA, 2003, pp.1-37.
[8] ACI Committee 318, "Building Code Requirements for Structural Concrete (ACI 318-M14)", American Concrete Institute, Detroit USA, 2014.

[9] Rudollph Szilard, Dr.-Ing., P.E., (2004), "Theories and Application of Plat Analysis", New Jersey, U.S.A, pp.6.

[10] ASTM A615, "Standard Specification for Deformed and Plain Carbon Structural Steel Bars for Concrete Reinforcement", Annual Book of ASTM Standards, Vol.01, No.02, 2005.

[11] ASTM C 143-03, "Standard Test Method for Slump of HydraulicCement Concrete", Annual book of ASTM standards.

[12] BS 1881-Part 116-2000, "Method for Determination of Compressive Strength of Concrete Cubes", British Standards Institute BSI, London, 2000,11p.

[13] ASTMC39, "Standard Test Method for Compressive Strength of Cylindrical Concrete Specimens" p.5, 2001.

[14] ASTM C496-04 "Standard Test Method for Splitting Tensile Strength of Cylindrical Concrete Specimens" Annual Book of American Society for Testing and Material Standards, Vol. 04.02 Concrete and Aggregate, West Conshohocken, PA, United States, pp.5.

[15] ASTM C78, "Standard Test Method for Flexural Strength of Concrete Using Simple Beam with Two Points Loading", Annual Book of ASTM Standard, Vol. 04, No.02, 2002.

[16] ASTM C469, "Standard Test Method for Static Modulus of Elasticity and Poisson's Ratio of Concrete in Compression", p5, 2002. 